\title{
編集委員長挨拶*
}

\author{
望月 修**

\section{Invitation to Editorial Works}

\author{
Osamu Mochizuki
}

可視化情報学会は会員の皆様のご支援で 2006 年にめ でたく創立 25 周年を迎えます。この間，学会誌は本会 の顔，情報発信源，交流という役割で毎年 4 号ずつ発刊 され，25 周年にあたる 2006 年の第 1 号 (1月発刊) が 通算で 100 号目となります. 第 16 期 (2004 年度), 第 17 期（2005 年度）の編集委員長を務めている間に，こ のような記念すべき号を発行できることは喜ばしいかぎ りです，それと同時に歴史の重さおよび責任の重さを認 識させられ，身が引き締まる思いでおります。ただし， 100 という「きりの良い」数字だから特別というのでは なく，我々編集委員にとってはどの号も重要で, 毎号毎 号に気を遣って取り組んでおります。ここで, 編集委員 会でどのように毎号の出版を実現しているかの一端を紹 介させて頂き，会員皆様のご理解とさらなるご協力をい ただければ幸いです。

1 つの号を発刊するのに，ほほ 1 年前に特集企画を行 います.トレンディーでホットな話題を取り上げること に主眼が抢かれることは当然ですが，過去に組んできた 特集記事の中で重複や酷似したものは無いか，もしある とすると異なる切り口で特集を組めるか, そのテーマで の特集を組める適切な人がいるか，などを検討します。 編集委員の中で選ばれた担当委員は適切な執筆者の内諾 を得るべく交涉を致します，数人の執筆者が決まります と執筆依頼をし，原稿を 2 ヶ月以内であげて頂きます. 原稿がそろった段階で本会誌のフォーマットにあうかど うかといった事務的処理を委貝と著者とのやりとりに よって行います．印刷所に原稿を提出した後，印刷前の 校正を担当委員と著者がそれぞれ行います：全て OKに なった段階で印刷発行となります。この間，編集員会の 幹事は，全ての号に関する発行までのプロセスにおいて 特集記事はもちろんのこと, その他の記事に関してもい ろいろと面倒を見ております。第 16，17 両期の幹事は 東大の杉井康彦先生, 染矢聡先生ですが, お二人の負担 はものすごいものがあります．毎号無事に発行できてい るのは扔二人のご尽力による賜物です。この紙面をお借 りしてお二人に感謝の意を表します。

これまでの特集テーマを 10 年前の 1996 年 1 月の「脳 機能をみる」(60 号) から，順に列記すると次のと拀り です.なお，（）内の数字は号数です. 表情を認識す

\footnotetext{
* 原稿受付 2005 年 11 月 4 日
}

** 正会員 東洋大学工学部
る (61), GPS の基礎と応用 (62), 原子・元素の可視 化 (63), 火山 (64), 色彩 (65), 情報のシンボル化 (66), 3 Dの世界 (67)，パソコン活用 (68), 模型表面流れを可 視化で読む(69)，非破壊検査に扔ける可視化で読む(70), 衛星画像利用環境評価 (71), 人間の思考の可視化 (72), 開発最前線に㧍ける可視化の利用 (73), 災害の予測 (74), 超音速・極超音速流れにおける可視化（75），マイクロ ビジュアリゼーション (76), PIV (77), 数值シミュレー ション情報の可視化 (78), 超音速燃焼一可視化と数值 シミュレーション (79), 気液二層流に扔ける可視化 (80), 企業による可視化の利用 (81), ウェーブレット解析の 可視化への展開 (82), 感圧涂料技術の新展開 (83), ゲ ノム解析における可視化情報 (84)，医療と可視化（85）, 地球環境情報の可視化 (86), 非ニュートン流体・粘弾 性流体の可視化 (87), 地図と GIS (88), 高速度ビデオ /カメラ撮影の最前線 (89), マイクロビジュアライゼー ション (90), 流体機械の可視化 (91), 可視化と相似模 型 (92), スポーツ工学 (93), 脳の構造と機能の可視化 (94)，可視化情報最前線（95），ダイナミックPIV（96）, 電子機器の開発・設計に関連した可視化 (97), 宇宙環 境利用に扔ける可視化 (98)，情報の可視化（99）です. これらは今でも決して古くなっていない内容で, テーマ 設定の先見性があることに，これまで編集に携わってこ られた方たちに敬意を表します。100号以降においても， 10 年, 20 年たった後に，扔もしろくまた決して内容が 古くなっていないと評される内容となるよう, 編集委員 一同切碰环磨していく所存でおります. 会員の皆様から も是非こんな内容のテーマを取り上げてほしいといった 要望を扔寄せ頂けると幸いです。会誌の内容充実にご参 加頂けるようお願い致します。

現在, 学会誌の印刷費, 発送費などに多額の費用がか さんで扔り，この見直し作業を行っているところです. これらを抑えることには限界があるため, 学会誌のあり 方そのものも見直す必要が出てきて扔ります。情報発信， 会員サービスといった学会誌のもつ役割を損なうことな く，新たな形態を探って行かねばなりません，100号を 期にこれから学会として何を目指すのかを考え，それを 達成するためにどの様な編集があり得るのか, 可視化情 報をどの様に伝えるのかといったことを皆㥞と共に考え ていきたく，よろしく㹉い致します。 